\title{
Investigation of the incidence and causes elite tennis players' injuries in Turkey
}

\author{
Orhan Ahmet SENER ${ }^{1}$, Serife CINAR ${ }^{2}$, Taner ZIYLAN²
}

${ }^{1}$ Department of Physical Education and Sport, Faculty of Sport Sciences, Selcuk University, Konya, Turkey.

${ }^{2}$ Department of Anatomy, Faculty of Medicine, KTO Karatay University, Konya, Turkey.

Address Correspondence to O. A. Sener, e-mail; oasener@selcuk.edu.tr

\begin{abstract}
Tennis which is a sport branch forcing technical, tactical, physiological and psychological capabilities of human is one of the best sports branches. "Sports Injuries" is referred to every kind of damage occurring during sportive activities. Several factors are involved in sports injuries including age, quality of the material used, weather, lighting, court, hall, component, physical condition of the athlete etc. In addition, psychological factor have also been stated to play a role in sports injuries. The study was performed with a questionnaire conducted on 86 elite male tennis players who were playing in Ankara, Konya and Istanbul regions at 1990-1991 season of Turkey Tennis Classification League. In study, 47 players have exposed to injury, while 39 have not. Rates of injuries were found to be higher in the shoulder, elbow, knee and ankle regions compared to the other parts of the body. In conclusion, in this study we found that the incidence of injury was $54.65 \%$ among male tennis player. In addition, our findings indicated that stressful events experienced by the tennis players were also effective on injuries.
\end{abstract}

Keywords: Causes of injury, injury incidence, tennis players.

\section{INTRODUCTION}

Tennis which is a sport branch forcing technical, tactical, physiological and psychological capabilities of human is one of the best sports branches that improve physical, mental, emotional and social development characteristics, when is played in a planned and programmed way(1). Tennis is a sportive game played by striking a hollow rubber felt-covered ball with a tool called racket to pass it over or around a net of $91 \mathrm{~cm}$ high on a smooth and hard ground. According to some, origin of tennis is based on a game named as 'trigon' which has been played with bare or gloved hands in the ancient Rome period. It is argued in another view that a similar game has been played for the first time by Toltec natives in Mexico (2).

"Sports Injuries" is referred to every kind of damage occurring during sportive activities. Injuries occur with the interruption of dynamic and coordinated movement flow due to any reason(3). Sport injuries have been classified as three groups by the American National Athletic Injury/Illness Reporting System: 1) Minor sports injuries; losing of 1-7 days lost from sportive activities. 2) Moderate sports injuries: 8-21 days lost. 3) Severe sports injuries: more than 21 days lost from sportive activities, sometimes resulting in permanent disability (4).

It is reported that several factors are involved in sports injuries including age, quality of the material used, weather, lighting, court, hall, component, physical condition of the athlete etc. In addition, psychological factor have also been stated to play a role in sports injuries (5).

It is an indisputable fact that, given the playing time all of the features such as strength, endurance, speed-velocity, mobility, skills and coordination are necessary in this sport (6). Lacking one of these features may cause sports injuries. Injuries that may occur are thought to be associated with psychosocial factors. In the present study, we investigated frequency, distribution and causes of injury in elite male tennis players and the relationship between injury and psychosocial factors involving stressful events in players' lives.

\section{MATERIAL \& METHODS}

The study was performed with a questionnaire conducted on 86 elite male tennis players who were playing in Ankara, Konya and Istanbul regions at 1990-1991 season of Turkey Tennis Classification League. In the questionnaire, tennis players were 
asked whether they have suffered injury, in which anatomic region the injury has occurred and cause of injury. In addition, the questionnaire included several questions such as have you lost your parents or a person who you cared for?', 'have you broken up with your beloved?' 'Have you divorced from your wife?' 'Have you lost your job?' 'Have you had to change your living environment?' 'Do your parents live separated due to severe conflict or have they divorced' and 'have you failed in your school or flunked? Statistical evaluation of the question involved in the questionnaire by taking percentage of the responses.

\section{RESULTS}

Mean age of male tennis players included in the study was found as 21.5 years with the youngest player being 16-year-old and the eldest player 37year-old. Of participant players, 47 have exposed to injury, while 39 have not (Table 1).

Table 1. Rate of injury in male tennis players.

\begin{tabular}{lcc} 
& $\mathrm{n}$ & $\%$ \\
\hline Injured player & 47 & 54.65 \\
Not injured player & 39 & 45.34 \\
Total & 86 & 100 \\
\hline
\end{tabular}

\begin{tabular}{lcc}
\multicolumn{3}{c}{ Table 2. Percentage of injuries during training and match. } \\
\hline & $\mathrm{n}$ & $\%$ \\
Injury during training & 39 & 82.98 \\
Injury during match & 8 & 17.02 \\
Total & 47 & 100 \\
\hline
\end{tabular}

Of the players who have suffered injury, 39 injured during training and 8 during match. The percentages are given in Table 2.

In the questionnaire, body's parts in which injuries have occurred were also evaluated. Rates of injuries were found to be higher in the shoulder, elbow, knee and ankle regions compared to the other parts of the body. Rate of injuries in the upper and lower extremities are given in Table 3.

Factors causing tennis injuries differed in various parts of the body. The most common factor was found as over use followed by sprain (Table 4).

Out of 47 individuals included in this study, 28 (59.57\%) have not experienced a stressful event before injury, while 19 (40.43\%) participants have suffered a stressful event before injury. Regions of injuries and rate injury factors in the individuals who have suffered stress are shown in Table 5.

Table 3. Rates of injuries according to body parts.

\begin{tabular}{lcc}
\hline Region of Injury & $\mathrm{n}$ & $\%$ \\
\hline Foot & 1 & 1.13 \\
Ankle & 8 & 17.07 \\
Achilles tendon & 5 & 10.64 \\
Lower leg & 2 & 4.26 \\
Knee & 7 & 14.89 \\
Thigh & 2 & 4.26 \\
Back & 4 & 8.51 \\
Shoulder & 8 & 17.02 \\
Upper arm & 1 & 2.13 \\
Tennis Elbow & 7 & 14.89 \\
Forearm & 1 & 2.13 \\
Hands & 1 & 2.13 \\
Upper Extremity & & \\
Total & 18 & 38.30 \\
Lower Extremity & & \\
Total & 25 & 53.19 \\
\hline
\end{tabular}

Table 5. Regions of injuries and rate of injury factors in the individuals who has suffered stress before injury.

\begin{tabular}{lccc} 
Region of injury & Injury factor & $\mathrm{n}$ & $\%$ \\
\hline Knee & Sprain & 6 & 31.57 \\
Ankle & Sprain & 5 & 26.32 \\
Elbow & Over use & 3 & 15.79 \\
Shoulder & Over use & 2 & 10.52 \\
Achilles Tendon & Over use & 2 & 10.52 \\
Forearm & Over use & 1 & 5.26 \\
\hline
\end{tabular}

Table 4. Rates of the factors causing injuries developed in tennis players according to the body parts.

\begin{tabular}{|c|c|c|c|c|c|}
\hline Region of injury & Over use & Muscular Injury & Sprain & Fracture & Contusion \\
\hline Foot & 1 & & & & \\
\hline Ankle & & & 8 & & \\
\hline Achilles tendon & 5 & & & & \\
\hline Lower leg & 2 & & & & \\
\hline Knee & 1 & & 6 & & \\
\hline Thigh & & 2 & & & \\
\hline Back & 2 & 2 & & & \\
\hline Shoulder & 6 & 2 & & & \\
\hline Upper arm & 1 & & & & \\
\hline Tennis Elbow & 7 & & & & \\
\hline Forearm & 1 & & & & \\
\hline Hands & & & & 1 & \\
\hline $\mathrm{N}(\%)$ & $26(53.31 \%)$ & $6(12.77 \%)$ & $14(29.79 \%)$ & $1(2.13 \%)$ & \\
\hline
\end{tabular}




\section{DISCUSSION}

Tennis is a global sport, with participation in more than 200 countries affiliated with the International Tennis Federation. It is also a professional sport in which millions of dollars in prize money are at stake for both men and women players (7). Especially, because performance sports require striving, these sports carry sometime great and sometimes small risks which occasionally cause injury, even death.

In the present study, rate of injury was found as $43.34 \%$ among all participants. In a study by Imamoğlu, injury rate of injury incidents was found to be higher during training in all male tennis players. When regions of injury were compared, the highest rate of injuries was found in lower and upper extremities. Other regions of injuries were found as the ankle by $17.07 \%$, Achilles tendon by $10.64 \%$, knee as $14.89 \%$, shoulder by 17.02 and elbow by $14.89 \%$.

In a study by Winge et al., rate of injury was found as $53.49 \%$ in Danish tennis players. In the same study, $63 \%$ of the injuried male tennis players were found to experience injury during training and $37 \%$ during match (8). While rate of injury was similar to that we found in this study, no similarity was observed in terms of the regions of injury. In a study by GarrckandRaxua comparing injuries in different sportive areas; rate of injury was found as $81 \%$ in football, $75 \%$ in wrestling, $40 \%$ in gymnastics, $28 \%$ in men's gymnastics and $30 \%$ in men's basketball (9).

Causes of tennis injuries have been reported by numerous authors as explosive movements, slipping and downfall due to court, racket properties, accidentally stepping on the ball, over use, muscular weakness and fatigue. In studies by Biener, acute injuries were stated as "my own fault" $(10,11)$. On the other hand, Kerr et al. explained causes of injury through a different approach.This model emphasizes external factors as well as internal factors including both physical and psychological features. Events posing negative or positive impact such as loss of mother or father, moving to a new house and marriage have been associated with injuries (12). According to our results; out of 47 participants exposed to injury; 28 (59.57\%) have not experienced a stressful event before injury, while 19
$(40.43 \%)$ participants have suffered a stressful event before injury.

In conclusion, in this study we found that the incidence of injury was $54.65 \%$ among male tennis player and the most common regions of injury were shoulder, elbow, hips and feet in the lower and upper extremities. In addition, our findings indicated that stressful events experienced by the tennis players were also effective on injuries. We believe that, results obtained in this study would provide contribution to further studies to be performed on this subject.

\section{REFERENCES}

1. Aktaş F. Kuvvet antrenmanının 12-14 yaş grubu erkek tenisçilerin motorik özelliklerine etkisi. Selçuk üniversitesi, Sağlık bilimleri enstitüsü. Konya 2010.

2. Arslan Y. Elit badminton ve tenis oyuncularının bazı antropometrik özellikleri ve oransal ilişkilerinin karşılaştırılması. Gazi Üniversitesi, Sağlık Bilimleri Enstitüsü, Ankara, 2009.

3. Yıldırım İ. Niğde ilinde okul basketbol takımlarında, basketbol oynayan sporcuların sakatlanma siklıkları ve nedenlerinin araştırılması. Niğde üniversitesi, Sosyal Bilimler Enstitüsü, Niğde, 2001.

4. Bavlı Ö, Kozanoğlu E. Adolesan basketbolcularda mevkilere göre yaralanma türleri ve nedenleri. F Ü Sağ Bil Derg, 2008;22:77-80.

5. Dorak F, Altıparmak T, Talas İ. Spor sakatlanmaları ile yaşam olayları arasındaki ilişki. Hacettepe Spor Bilimleri Dergisi. 1998;1:30-43.

6. Atlı M, Temus HB, Gencer G, Şensoy N. Yüzüncü yıl üniversitesi tenis takımı sporcularının biyometrik özelliklerinin sedanterlerle karşılaştırılması. VAN/YYÜ Eğitim Fakültesi Dergisi, 2011;175-181.

7. Pluim BM, Staal JB, Windler GE, Jayanthi N. Tennis injuries: occurrence, aetiology and prevention. Br J Sports Med, 2006;40:415-423

8. Winge SJorgensen U, Nielsen L. Epidemiology of injuries in Danish Championship Tennis. Int J Sports Med,1989;10:368371.

9. Gaddick J, Requa R. Medical care and injury surveillance in the high school setting. Physician and Sportsmedicine,1981;9:115-120.

10. Biener K, Fassler. Sportunfalle auft, Bern, Stutgart, Wien: Huber. 1978;105-104.

11. Biener K. Edidemioloqie und preventation Hefte Unfallheikunde. 1978;130:374-381.

12. Kerr G, Cairns L. The relationship of selected pyschological factors to athletic injury occurrence. Journal of Sport and Exercise Psychology,1988;10(2):167-173. 